\title{
Sistem Informasi Kegiatan Rumah Qur'an Tegal Dengan metode Waterfall
}

\author{
Sopian Aji ${ }^{1}$, Angga Ardiansyah², Dany Pratmanto ${ }^{3}$ \\ 1,2,3 Sistem Informasi, Sekolah Tinggi Manajemen Informatika dan Komputer Nusa Mandiri \\ Jakarta Indonesia \\ 15sopian.sop@nusamandiri.ac.id, 2angga.axr@nusamandiri.ac.id, 33any.dto@nusamandiri.ac.id
}

\begin{abstract}
In the current era, information technology is growing very rapidly, especially developments in information systems. The information system is one of the supports of an agency, both government and private institutions, from the fields of economy, business to education. Rumah Qu'an Tegal is a non-formal educational institution that is engaged in Al-Qur'an Education. With the many activities in Qu'an House it will be very time consuming if all data is managed manually, an information system that can be used is needed. To assist management in managing activity data easily, effectively and efficiently by using a website-based information system. The website is a form of information system that is often used, the website can display all forms of information digitally in the form of text, images, and animations that can be accessed quickly and realtime using an internet connection, can be accessed anywhere, anytime., so it is very helpful in the process of disseminating information, because it can be conveyed quickly. The method used in the development of information systems is to use the Waterfall method. This information system is built using the programming language PHP, HTML, CSS, Javascript in a codeigniter framework using an atomic text editor. The results of this study are the use of user information systems, namely the Muslim community generally knows if starting from carrying out activities to carrying out activities, facilitating information to become students and students, as well as other information accurately, efficiently and relevant.
\end{abstract}

Keywords: Website, Information System, Waterfall, Codelgniter

\begin{abstract}
Abstrak: Pada era sekarang ini teknologi informasi berkembang sangat pesat, terutama perkembangan pada sistem informasi. Sistem informasi merupakan salah satu penunjang dari suatu instansi, baik instansi pemerintah, swasta, dari bidang ekonomi, bisnis hingga pendidikan. Rumah Qu'an Tegal merupakan sebuah lembaga pendidikan non formal yang bergerak dalam bidang Penddikan Al-Qur'an, Dengan banyaknya kegiatan yang ada di Rumah Qu'an akan sangat memakan waktu jika semua data dikelola secara manual, maka diperlukan suatu sistem informasi yang dapat membantu pengurus dalam mengelola data kegiatan dengan mudah, efektif dan efisien yaitu dengan menggunakan sistem informasi bebasis website. Website merupakan salah satu bentuk sistem infromasi yang sering digunakan, pada website dapat menampilkan segala bentuk informasi secara digital baik itu dalam bentuk teks, gambar, dan animasi yang dapat diakses secara cepat dan realtime dengan menggunakan koneksi internet, dapat diakses dimana saja, dan kapan saja, sehingga sangat membantu dalam proses penyebaran informasi, karena dapat tersampaikan dengan cepat. Metode yang digunakan dalam pembagunan sistem informasi adalah dengan menggunakan metode Waterfall. Sistem informasi ini dibangun dengan menggunakan bahasa pemrograman PHP, HTML, CSS, Javascript dalam framework codeigniter dengan menggunakan text editor atom. Hasil dari penelitian ini adalah penggunaan sistem informasi user yakni masyarakat muslim umumnya mengetahui jika mulai dari akan mengadakaan kegiatan sampai dengan telah melaksanakan kegiatan, memudahkan informasi menjadi santiwa dan santriwati, serta informasi lainya secara akurat, efisien dan relevan.
\end{abstract}

Kata kunci: Website, Sistem Informasi, Waterfall, Codelgniter 


\section{A. PENDAHULUAN}

Pada era sekarang ini teknologi informasi berkembang sangat pesat, terutama perkembangan pada sistem informasi. Sistem informasi merupakan salah satu penunjang dari suatu instansi, baik instansi pemerintah, swasta, dari bidang ekonomi, bisnis hingga pendidikan. Website atau web merupakan salah satu bentuk sistem infromasi yang sering digunakan, pada website dapat menampilkan segala bentuk informasi secara digital baik itu dalam bentuk teks, gambar, dan animasi yang dapat diakses secara cepat dan realtime dengan menggunakan koneksi internet, dapat diakses dimana saja, dan kapan saja, sehingga sangat membantu dalam proses penyebaran informasi, karena dapat tersampaikan dengan sangat cepat.

Sistem Informasi adalah suatu kombinasi teratur daru orang-orang, hardware, software, jaringan komunikasi dan sumber daya data yang mengumpulkan, mengubah dan menyebarkan informasi dalam sebuah organisasi (Anggraeni \& Irviani, 2017). SMP Islam Al-Fatah memerlukan suatu rancang bangun sistem informasi akademik dengan dukungan web untuk membantu mengatasi permasalahan mengenai presensi siswa harian, nilai-nilai ulangan baik harian maupun tengah dan akhir semester secara detil, hingga kegiatan-kegiatan di sekolah(Suryadithia et al., 2019). Pembangunan sistem informasi akademik ini dapat membantu masyarakat dan warga sekolah mengakses informasi mengenai SMK.S Al Habibatain Bumiayu dengan cepat, mudah, dan efisien, dan dapat dilakukan di manapun (Mukrodin, 2020). Dalam perancangan system organisasi ini digunakan metode pengembangan system Waterfall, Alat yang digunakan dalam desain pengembangan system ini adalah UML dengan bahasa program yang digunakan PHP dan database Mysql (Jannah, 2019). Pada sistem sekolah dengan menggunakan teknologi terkomputerisasi salah satunya adalah untuk masalah penerimaan siswa baru pada sekolah AsSabiquun metode yang digunakan dalam pengembangan sistem ini adalah dengan menggunakan metode Waterfall, Hasil dari penelitian ini adalah berupa sistem informasi penerimaan siswa baru(Yuliandari et al., 2020). Rancangan sistem ini menghasilkan aplikasi SIPSIBA (Sistem Informasi Penerimaan Siswa Baru) dengan menggunakan metode Waterfall yang menyertakan tools sistem yaitu data flow diagram (DFD), entity relationship diagram (ERD) dan logical relational structure (LRS) Pemanfaatan teknologi informasi dengan merancang user interface aplikasi SIPSIBA yang user friendy akan memudahan user dalam penggunaannya(Hartati \& Sintawati, 2020)

Rumah Qu'an Tegal merupakan sebuah lembaga pendidikan non formal yang bergerak dalam bidang Pendidikan Al-Qur'an untuk semua umur dan kalangan yang dikombinasikan dengan basis kemandirian dan pengelilaan pemberdayaan santri serta masyarakat didaerah kota/kab Tegal dan sekitarnya. Dengan banyaknya kegiatan yang ada di Rumah Qur'an akan sangat memakan waktu jika semua data dikelola secara manual, maka diperlukan suatu sistem informasi yang dapat membantu pengurus dalam mengelola data kegiatan dengan mudah, efektif dan efisien yaitu dengan menggunakan sistem informasi bebasis website infomasi yang disampaikan dapat tersampaikan secara meluas, cepat, mudah, dan efisien, dan dapat dilakukan di manapun.

\section{B. TINJAUAN PUSTAKA}

\section{Metode Waterfall}

Waterfall adalah tahapan dart beberapa fase secara berurutan. Pada prosesnya tahapan yang dilakukan adalah satu per satu diselesaikan terlebih dahulu kemudian melangkah pada tahap berikutnya setelah sepenuhnya selesai. Untuk alasan ini, model Waterfall adalah rekursif dalam setiap Ease yang dapat diulang tanpa henti sampai itu disempurnakan dimulai dari identifilcasi masalah, desain sistem, implementasi, testing, uji coba dan maintenance jika pada tahapan uji coba belum sesuai dengan basil yang tidak sesuai dengan hasil maka tahapan penelitian akan dilakukan evaluasi mulai identifikasi masalah (Solehatin \& Anam, 2019). 


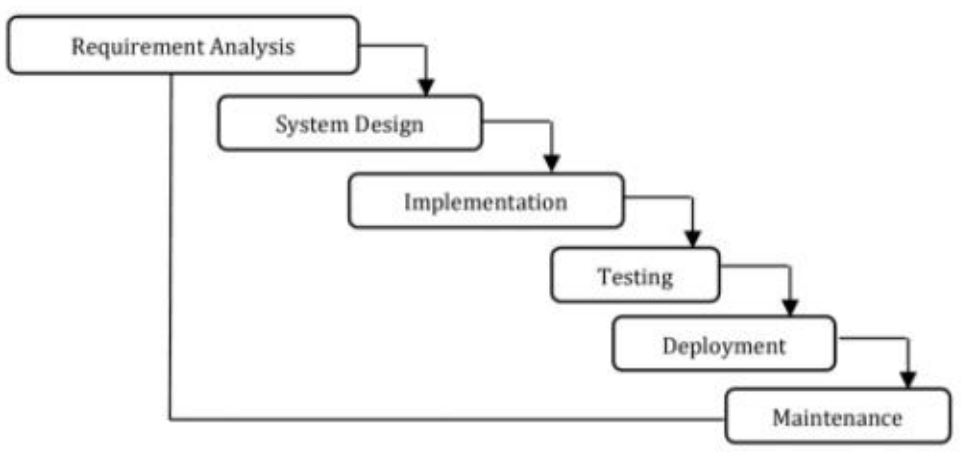

Gambar 1. Tahapan-Tahapan Metode Waterfall (Solehatin \& Anam, 2019)

Tahapan-tahapan metode Waterfall dalam (Fathoroni et al., 2020) yakni dengan beberapa tahapan yang berurut sebagai berikut:

1. Requirement Analisis

Tahap ini pengembang sistem diperlukan komunikasi yang bertujuan untuk memahami perangkat lunak yang diharapkan oleh pengguna dan batasan perangkat lunak tersebut. Informasi ini biasanya dapat diperoleh melalui wawancara, diskusi atau survei langsung. Informasi dianalisis untuk mendapatkan data yang dibutuhkan oleh pengguna.

2. System Design

Spesifikasi kebutuhan dari tahap sebelumnya akan dipelajari dalam fase ini dan desain sistem disiapkan. Desain Sistem membantu dalam menentukan perangkat keras(hardware) dan sistem persyaratan dan juga membantu dalam mendefinisikan arsitektur sistem secara keseluruhan.

3. Implementation

Pada tahap ini, sistem pertama kali dikembangkan di program kecil yang disebut unit, yang terintegrasi dalam tahap selanjutnya. Setiap unit dikembangkan dan diuji untuk fungsionalitas yang disebut sebagai unit testing.

4. Integration \& Testing

Seluruh unit yang dikembangkan dalam tahap implementasi diintegrasikan ke dalam sistem setelah pengujian yang dilakukan masing-masing unit. Setelah integrasi seluruh sistem diuji untuk mengecek setiap kegagalan maupun kesalahan.

5. Operation \& Maintenance

Tahap akhir dalam model Waterfall. Perangkat lunak yang sudah jadi, dijalankan serta dilakukan pemeliharaan. Pemeliharaan termasuk dalam memperbaiki kesalahan yang tidak ditemukan pada langkah sebelumnya. Perbaikan implementasi unit sistem dan peningkatan jasa sistem sebagai kebutuhan baru

\section{METODE PENELITIAN}

Metode penelitan yang dilakukan oleh peneliti disini metode yang digunakan adalah metode

Waterfall, dengan tahapan-tahapan sebagai berikut:

1. Analisa Kebutuan

Analisa kebutuhan dibagi menjadi dua yaitu fungsional dan non fungsional. Analisa kebutuhan fungsional yaitu sistem ini dibuat berfungsi untuk mengolah data panti dengan dua hak akses yaitu admin dan pengurus. Analisa kebutuhan non fungsionsl dibagi menjadi dua yaitu perangkat lunak (software) dan perangkat keras (hardware). Adapun Perangakat keras yang digunakan penulis adalah processor intel core i3, RAM 8 GB. Analisa kebutuhan perangkat lunak (software) dalam pembuatan sistem yaitu Sistem Operasi Windows 10 Pro 64-bit, XAMPP versi 7.3.11, Text Editor Atom dan framework codeigniter. 
2. Desain

Pada tahap ini penulis melakukan perancangan program dalam bentuk Entity Relationship Diagram (ERD) dan Logical Record Structure (LRS) dalam merancang databases. Desain dibuat agar dengan mudah dalam melakukan pengolahan data yang diperlukan.

3. Pembuatan Kode Program

Berdasarkan desain program yang telah dibuat, kemudian merancang pemprograman menggunakan bahasa pemrograman PHP, HTML, CSS, Javascript dalam framework codeigniter dengan menggunakan text editor atom.

4. Pengujian

Tahap ini akan dilakukan saat aplikasi sistem informasi selesai dibuat. Metode yang digunakan pada tahap pengujian ini adalah metode blackbox testing, berguna untuk validasi apakah program sudah sesuai dengan kebutuhan yang telah dirancang atau belum.

5. Pemeliharaan (maintenance)

Program yang telah selesai dibuat membutuhkan pemeliharaan untuk memperbaiki kesalahan yang ada pada tahap sebelumnya. Dalam tahap ini juga dilakukan pengembangan seperti penambahan fitur-fitur baru.

Dalam melakukan pengumpulan data peneliti ini melakukan teknik pengumpulan data sebagai berikut :

a. Observasi

Peneliti melaksanakan pengamatan langsung pada Rumah Qur'an Tegal, yang berkedudukan di jalan Merpati no. 114 Kel. Randugunting, Kec. Tegal Selatan Tegal Selatan. Pada Penelitian ini penelitian langsung mempelajari data yang berhubungan dengan perancangan aplikasi yang dibutuhkan.

b. Wawancara

Peneliti melakukan tanya jawab secara langsung dengan Moh. Hidayat Catur Mardiko sebagai Koordinator yang dalam hal ini bertindak untuk dan atas nama Rumah Qur'an Tegal.

\section{HASIL DAN PEMBAHASAN}

\section{Planning}

Sistem informasi pada Rumah Qur'an Tegal membutuhkan peran sebagai administrator dimana berperan untuk mengelola data berupa berita atau informasi yang akan disampaikan kepada user atau pengunjung website www.rumahqurantegal.com. Sistem menyediakan menu login untuk masuk kehalaman administrator, halaman berita berupa kegiatan atau artikel, infomasi lainnya seputar Rumah Qur'an seperti profil, visi misi, lokasi, kontak dan lainnya.

\section{Disain}

Use Case Diagram pada sistem informasi pada Rumah Qur'an adalah sebagai berikut:

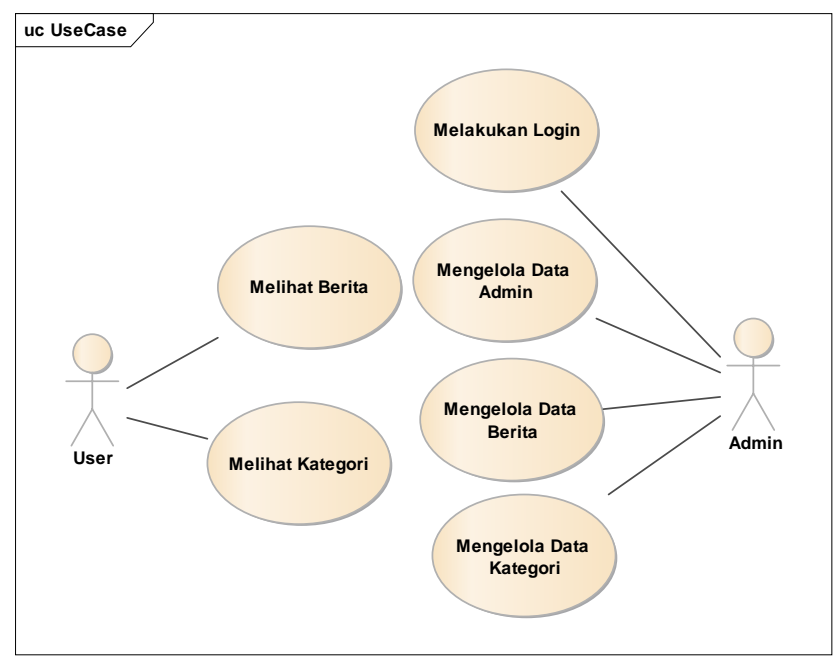

Gambar 2. Use Case Sistem Informasi Rumah Quran 
Pada gambar 2 menunjukan terdapat 2(dua) aktor yaitu user dan admin. Pada aktor user menggambar sebagai pengguna atau pengunjung website, dimana user bisa melihat berita secara keseluruhan atau melihat berita berdasarkan kategori yang telah tersedia. Sedangkan pada aktor Admin adalah sebagai administrator dimana berperan untuk mengelolah data admin, mengelola data berita, mengelola data kategori dan sebelum masuk pada halaman administrator diminta untuk melalukan login terlebih dulu.

Gambar Activity Diagram pada sistem informasi Rumah Qur'an Tegal pada user atau pengunjung website sebagai berikut:

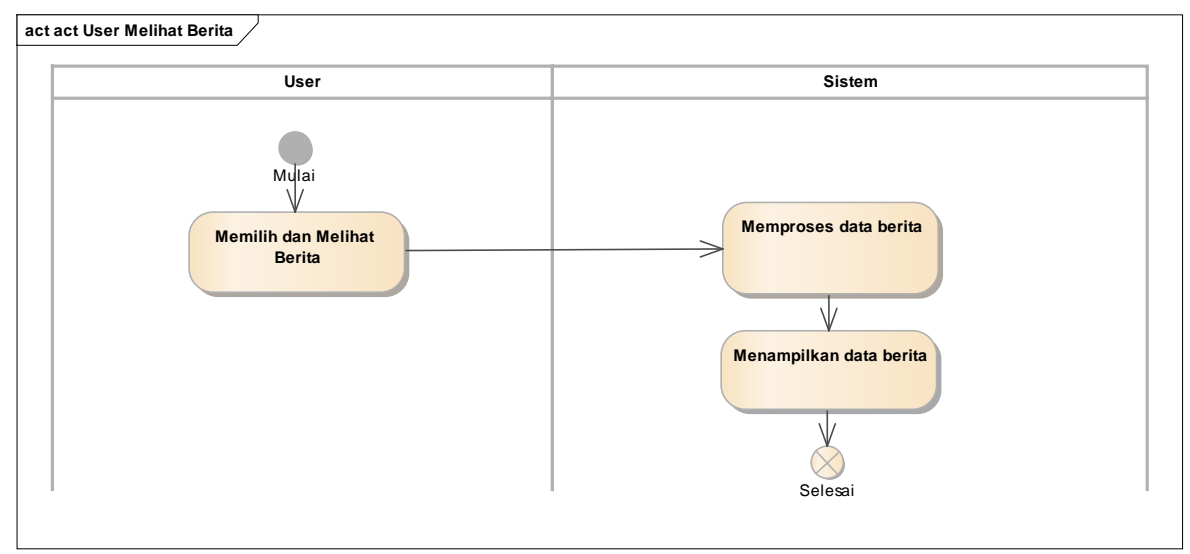

Gambar 3. Activity Diagram User Melihat Berita

Pada gambar 3 menggambarkan kegiatan user atau pengunjung saat user mengunjungi website www.rumahqurantegal.com peran user disini adalah user bisa melihat berita yang telah dipulish oleh admin atau administrator, pada halaman ini user bisa memilih dan melihat berita sesuai dengan pilihan berita atau artikel yang dipilih oleh user itu sendiri. Sedangkan gambaran dari Activity Diagram pada sistem informasi Rumah Qur'an Tegal pada pengelolaan data berita pada halaman admin sebagai berikut

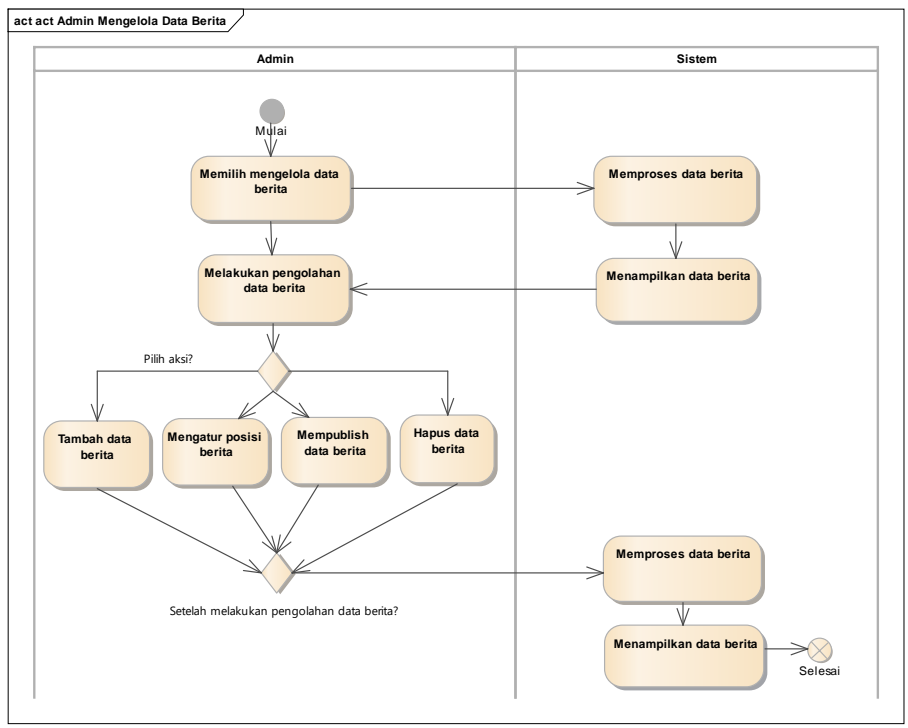

Gambar 4. Activity Diagram Admin mengelola data berita

Pada gambar 4 menunjukan pengelolaan data berita dimana pada halaman ini adalah halaman administrator dimana admin bertugas memberikan informasi kepada user atau pengunjung dalam bentuk berita. Pada menu berita terdapat 4(empat) menu pilihan dalam mengelola berita diantaranya yaitu tambah data berita yang berfungsi untuk menambahkan berita baru, atur posisi berita berfungsi untuk mengatur berita tetap pada posisi teratas berita sebagai 
berita utama pada halaman user, publish data berita berfungsi untuk mem-pulish berita agar berita bisa dibaca oleh user atau pengunjung, dan terakhir hapus data berita berfungsi untuk menghapus berita.

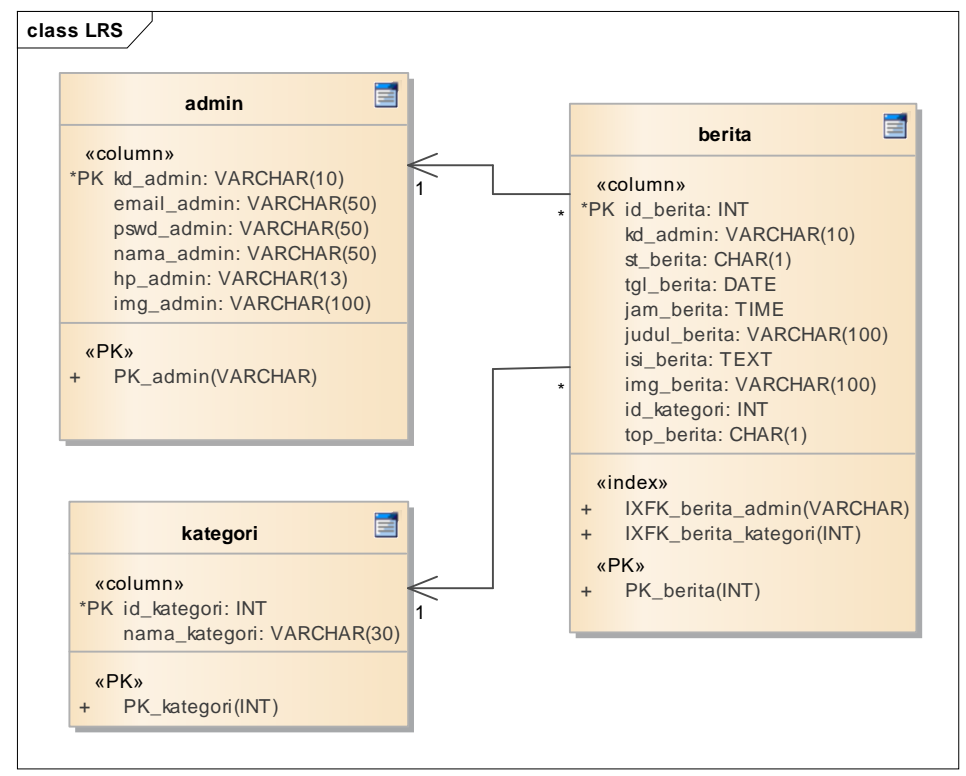

Gambar 5. LRS (Logical Record Structure) Pada Databases

Gambar 5 menunjukkan LRS (Logical Record Structure) databases yang digunakan website sistem informasi Rumah Qur'an Tegal yang terdiri dari 3(tiga) tabel yang saling ber-relasi yaitu tabel admin berfungsi menyimpan data user yang memiliki akun masuk kehalaman administrator, tabel berita berfungsi untuk menyimpan data berita sedangkan kategori berfungsi untuk mengelompokkan data berita sesui denga nisi berita yang diberikan.

\section{User Interface Halaman User}

Halaman utama user saat mengunjungi website www.rumahqurantegal.com sebagai berikut

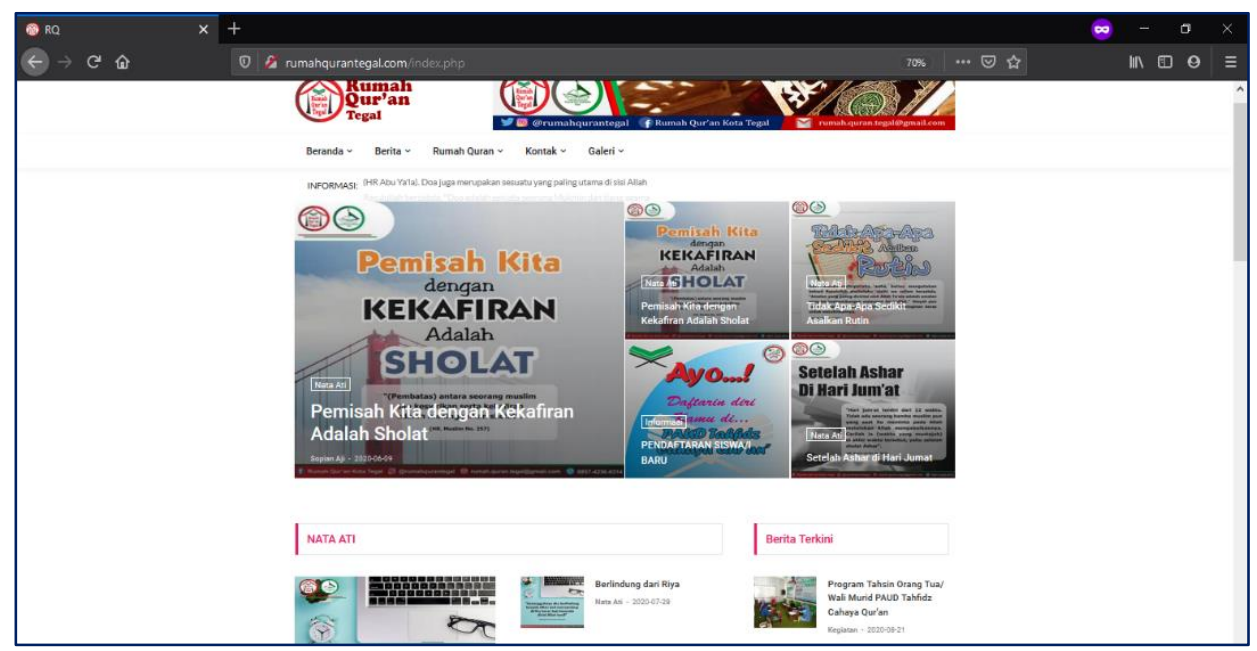

Gambar 6. Tampilan Halaman Beranda User

Pada Gambar 6 menunjukan halaman utama atau halaman beranda saat websitu dikunjungi secara otomatis user atau pengunjung akan membukakan halaman ini, dengan demikian user atau pengunjung dapat mengetahui berita atau informasi terbaru pada website tersebut. 
Sedangkan pada halaman berita kita bisa melihat User Interface sebagai berikut:

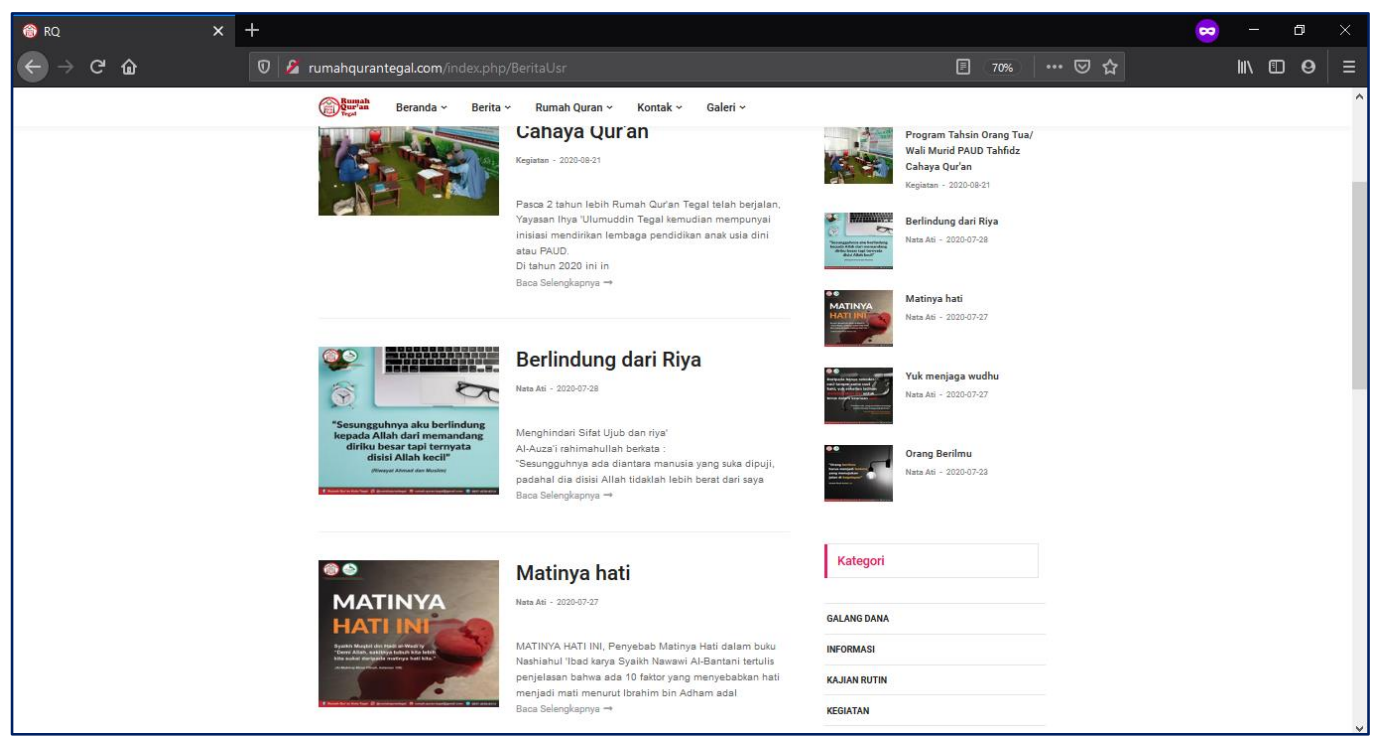

Gambar 7. Tampilan Halaman Beranda User

Pada halaman berita atau artikel user atau pengunjung bisa melihat berita terbaru sampai berita terlawas yang tersedia pada berita, selain itu user atau pengunjung juga dapat membaca berita atau artikel berdasarkan kategori yang tersedia.

\section{User Interface Halaman User}

Halaman login masuk sebagai administrator sebagai berikut ini:

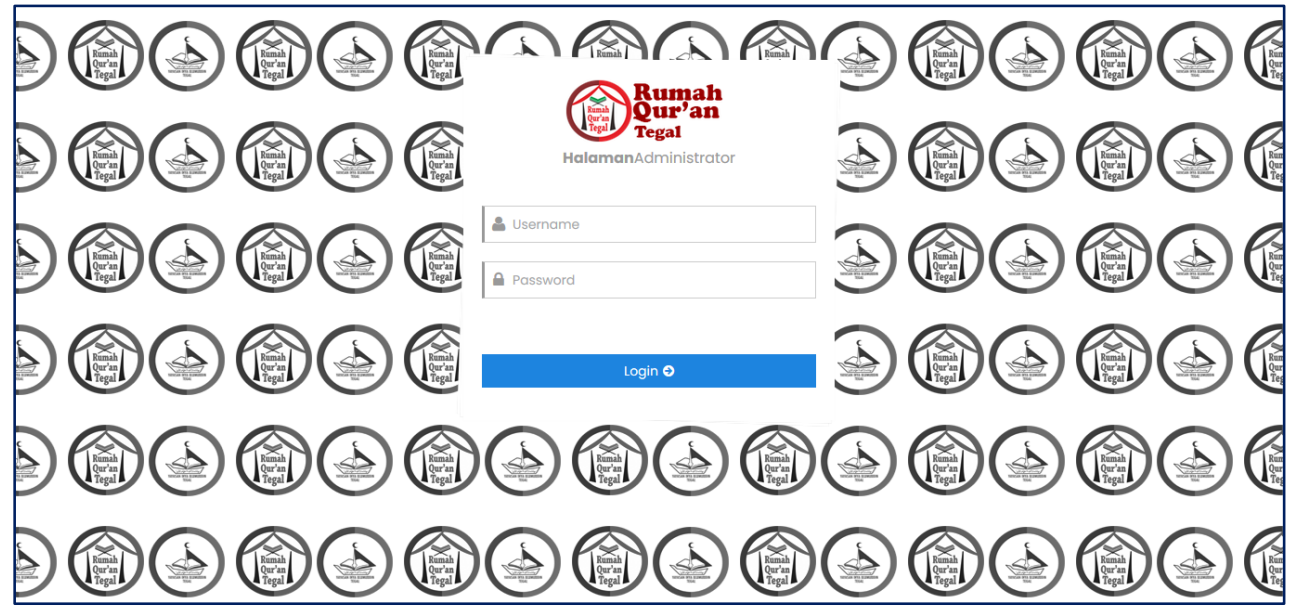

Gambar 8. Halaman Login Administrator

Halaman administrator pada gambar 8 ini akan muncul Ketika admin akan masuk pada halaman administror, admin diminta login terlebih dulu yang telah dipercapa atau yang telah memiiki akun untuk mengelola website Rumah Qur'an Tegal. Admin dapat masuk kehalaman administrator dengan memasukkan usemame dan password. Halaman pada administartor untuk mengelola berita adalah halaman utama saat admin mengelola berita yang akan disampaikan kepada pengunjung, baik berita terbaru sampai dengan berita terlawas atau mengampaikan 
berita berdasarkan kategori, dengan tampilan halaman berita sebagai berikut ini:

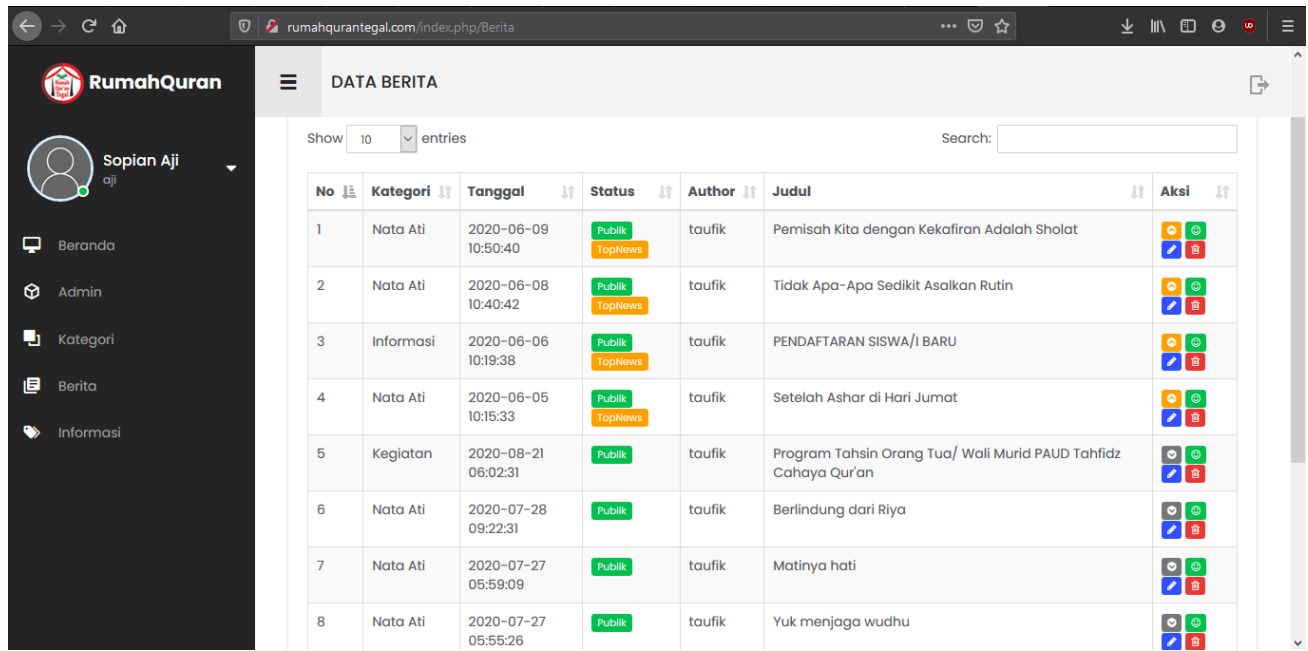

Gambar 9. Halaman pada Administartor Untuk Mengelola Berita

Pada Halaman ini, admin pada mengelola berita baik membuat berita baru, memperbaharui berita, mengatur posisi berita, memblok atau mempublish berita sampai dengan menghapus berita. Pada halaman ini admin bisa melihat author yang bertanggung jawab pada berita tersebut selain itu kita bisa melihat berita berdasarkan kategori, tanggal berita dan status berita itu sendiri apakah berita tersebut diposisi diatas, berita dipublis atau berita diblok (tidak ditampilkan pada halaman user).

\section{Pengujian Unit}

Berikut merupakan pengujian sistem informasi kegiatan Rumah Qur'an Tegal menggunakan blackbox testing yang fokus terhadap proses masukan dan keluaran program:

Tabel 1. blackbox testing Form Tambah Berita

\begin{tabular}{|c|c|c|c|c|c|}
\hline No & $\begin{array}{l}\text { Skenario } \\
\text { Pengujian }\end{array}$ & Test case & Hasil yang diharapkan & $\begin{array}{c}\text { Hasil } \\
\text { Pengujian }\end{array}$ & Kesimpulan \\
\hline 1. & $\begin{array}{l}\text { Semua data tidak } \\
\text { diisi kemudian klik } \\
\text { tombol simpan }\end{array}$ & $\begin{array}{l}\text { Judul Berita: } \\
\text { (kosong) }\end{array}$ & $\begin{array}{lr}\text { Sistem akan } & \text { menolak } \\
\text { akses dan muncul } \\
\text { peringatan "Judul Berita } \\
\text { Harus di Isi" }\end{array}$ & $\begin{array}{l}\text { Sesuai } \\
\text { harapan }\end{array}$ & valid \\
\hline 2. & $\begin{array}{l}\text { Salah satu data } \\
\text { saja yang di isi } \\
\text { kemudian klik } \\
\text { tombol simpan }\end{array}$ & $\begin{array}{l}\text { Judul Berita: } \\
\text { Tes Isi Judul, } \\
\text { Kategori: } \\
\text { (tidak dipilih) }\end{array}$ & $\begin{array}{l}\text { Sistem akan menolak } \\
\text { akses dan muncul } \\
\text { peringatan "Pilih } \\
\text { Kategori Harus di Isi" }\end{array}$ & $\begin{array}{l}\text { Sesuai } \\
\text { harapan }\end{array}$ & valid \\
\hline 3. & $\begin{array}{l}\text { Data disi pada: } \\
\text { judul berita dan } \\
\text { kategori, kemudian } \\
\text { klik tombol simpan }\end{array}$ & $\begin{array}{l}\text { Judul Berita: } \\
\text { Tes Isi Judul, } \\
\text { Kategori: } \\
\text { Kajian Rutin, } \\
\text { Isi Berita } \\
\text { (kosong) }\end{array}$ & $\begin{array}{lr}\text { Sistem akan } & \text { menolak } \\
\text { akses dan } & \text { muncul } \\
\text { peringatan "Isi } & \text { Berita } \\
\text { Harus di Isi" } & \end{array}$ & $\begin{array}{l}\text { Sesuai } \\
\text { harapan }\end{array}$ & valid \\
\hline 4. & $\begin{array}{l}\text { Data disi pada: } \\
\text { judul berita, } \\
\text { kategori dan Isi } \\
\text { berita, kemudian } \\
\text { klik tombol simpan }\end{array}$ & $\begin{array}{l}\text { Judul Berita: } \\
\text { Tes Isi Judul, } \\
\text { Kategori: } \\
\text { Kajian Rutin, } \\
\text { Isi Berita: } \\
\text { Tes Isi Berita, } \\
\text { Foto Berita: } \\
\text { (Gambar tidak di } \\
\text { unggah) }\end{array}$ & $\begin{array}{l}\text { Sistem akan } \\
\text { akses dan munculak } \\
\text { peringatan } \\
\text { Harus di Ungah" }\end{array}$ & $\begin{array}{l}\text { Sesuai } \\
\text { harapan }\end{array}$ & valid \\
\hline
\end{tabular}




\begin{tabular}{|l|l|l|l|l|l|}
\hline 5. & $\begin{array}{l}\text { Semua data disi, } \\
\text { namun foto berita } \\
\text { tidak sesuai format } \\
\text { gambar kemudian } \\
\text { klik tombol simpan }\end{array}$ & $\begin{array}{l}\text { Judul Berita: } \\
\text { Tes Isi Judul, } \\
\text { Kategori: } \\
\text { Kajian Rutin, } \\
\text { Isi Berita: } \\
\text { Tes Isi Berita, } \\
\text { Foto Berita: } \\
\text { (format foto tidak } \\
\text { sesuai) }\end{array}$ & $\begin{array}{l}\text { Sistem akan menolak } \\
\text { akses dan muncul } \\
\text { peringatan "Format } \\
\text { gambar yang digunakan } \\
\text { jpeg I jpg | png" }\end{array}$ & $\begin{array}{l}\text { Sesuai } \\
\text { harapan }\end{array}$ & valid \\
\hline 6. & $\begin{array}{l}\text { Semua data disi } \\
\text { dan foto berita } \\
\text { sesuai format } \\
\text { gambar kemudian } \\
\text { klik tombol simpan }\end{array}$ & $\begin{array}{l}\text { Judul Berita: } \\
\text { Tes Isi Judul, } \\
\text { Kategori: } \\
\text { Kajian Rutin, } \\
\text { Isi Berita: } \\
\text { Tes Isi Berita, } \\
\text { Foto Berita: } \\
\text { (format foto sesuai) }\end{array}$ & $\begin{array}{l}\text { Sistem akan menyimpan } \\
\text { data dan akan muncul } \\
\text { notifikasi: "Data berhasil } \\
\text { Tersimpan". }\end{array}$ & Sesuai \\
harapan & valid & \\
\hline
\end{tabular}

\section{Pemeliharaan (Maintenance)}

Website www.rumahqurantegal.com membutuhkan pemeliharaan, perbaikan dan perlunya dilakukan pengembangan lebih lanjut lagi seperti penambahan fitur-fitur baru guna pengembangan sistem sesuai dengan kebutuhan pada Rumah Qur'an Tegal.

\section{E. KESIMPULAN}

Sistem Informasi Rumah Quran Tegal adalah penyampaian informasi yang dapat diakses secara online kepada masyarakat muslim khususnya baik santiwa dan santriwati yang telah menjadi anggota Rumah Quran mapun yang belum menjadi santiwa dan santriwati Rumah Quran. Isi berita yang disampaikan bisa berupa kerohani untuk meningkatkan keimanan umat muslim, seputar kegiatan yang telah dilakukan atau pun sebelum kegiatan berlangsung dengan tujuan menginformasikan bahwa Rumah Quran akan mengadakan kegiatan ataupun pengajian baik yang bersifat umum atau pun khusus untuk santiwa dan santriwati Rumah Quran.

Selanjutnya tentu saja Perlu adanya penelitian lanjut untuk menguji kualitas, menguji penerimaan sistem kepada pengguna aplikasi ini sebagai informasi dan masukan guna pengembangan sistem selanjutnya.

\section{REFERENSI}

Anggraeni, E. Y., \& Irviani, R. (2017). Pengantar Sistem Informasi. Penerbit Andi.

Fathoroni, A., Fatonah, R. N. S., Andarsyah, R., \& Riza, N. (2020). Memahami Metode Omax dan Promethee pada Sistem Pendukung Keputusan. Kreatif Industri Nusantara.

Hartati, T., \& Sintawati, I. D. (2020). Implementasi Metode Waterfall pada Perancangan Aplikasi SIPSIBA ( Studi Kasus SMK Muhammadiyah 10 Jakarta ). Remik Riset Dan E-Jurnal Manajemen Informatika Komputer, 5(1).

Jannah, M. (2019). Perancangan Sistem Informasi Pendaftaran Organisasi Unit Kegiatan Khusus (UKK) Berbasis WEB Di IAIN Bukittinggi. Jurnal Informatika, 6(2), 185-192.

Mukrodin. (2020). Implementasi Metode Waterfall Dalam Membangun Sistem Informasi Sekolah Di SMK.S Al Habibatain Bumiayu. ZONAsi: Jurnal Sistem Informasi, 2(1), 34-47.

Solehatin, \& Anam, C. (2019). E-Quisioner Terhadap Tingkat Pemanfaatan Layanan Wi-Fi Kabupaten Banyuwangi. Deepublish.

Suryadithia, R., Faisal, M., \& Priyono. (2019). Rancang Bangun Sistem Informasi Akademik Berbasis Web Dengan Metode Waterfall. Seminar Nasional Inovasi Dan Tren (SNIT), 1(Juni 2019), A-134-A-139.

Yuliandari, D., Wijayanti, D., Kurniawan, \& Komalasari, Y. (2020). Sistem Informasi Penerimaan Siswa Baru Dengan Model Waterfall Pada Yayasan As-Sabiquun. Bina Insani ICT, 7(1), 8392. 